\title{
Agri-Food Chains Versus Short Chains - Literature and Legislation Review
}

Daniela POPA ${ }^{1}$

\begin{abstract}
This study started from the premise that between the notions of short chain and agrifood chain there is a relationship as part to whole, and this paper aims to identify the differences between the two notions. Also, the concept of "local food system" will be analyzed, as it includes a short chain or a direct sale that meets other features. The study presents the triple end result approach of sustainable agriculture in the context of the creation of short chains or agri-food chains by showing off the benefits of these systems on the social, financial and environmental environment. At the end a study case for Romania high lightens the importance of creating and developing short food supply chains and the importance of support associations.
\end{abstract}

Keywords: short chain, agri-food chain, local food system, DPO, PGI.

JEL classification: D12, L17, L25, R58

DOI: $10.24818 /$ RMCI.2021.1.110

\section{Introduction}

Population growth is one of the phenomena that exerts the greatest pressure on international organizations and on the states of the world, which seek to develop in their legislation various models through which to make food supply more efficient. Sustainability issues will play an extremely important role in building the future strategies of all organizations working in the field (B. Petersen et. al. 2014). Sustainable agriculture is extremely important for any country, because the issue of food security and food safety is closely linked to public health (F. Zecca \& N. Rastorgueva 2014).

The organizations' approaches take into account the conservation of local heritage and the development of the rural environment, in the context of globalization, by creating levers for capitalizing on local products. However, with regard to short agri-food chains, maintaining the high quality of the product in the chain from producer to consumer through as few intermediaries as possible is essential for maintaining a good price and increasing the sustainability of small producers. Thus, it results that the two concepts, sustainability and conservation of local heritage, are closely linked. By developing short chains for local products, certain rural areas are developed sustainably and traditions are preserved.

\footnotetext{
${ }^{1}$ Popa Daniela, The Bucharest University of Economic Studies, Faculty of Economics of Agri-Food And Environmental, E-mail: dana.popa@madr.ro, Telephone: (+4)722.56.30.85
}

110 Review of International Comparative Management Volume 22, Issue 1, March 2021 


\section{The concept of "AGRI-FOOD CHAIN"}

The agri-food product chain is defined in GEO 103/2008 [19] as "the system of functional relations linking producers, processors, carriers, depositors, distributors, traders and / or commodity exchanges that trade the same product or group of products, in order to its or their use and / or consumption '. The term "supply chain" was invented by the French agronomist Louis Malassis (et al. 1992, p.94) and is defined as the route taken by a product (or group of products) within the agri-food system and which includes all agents (enterprises and producers) and operations (production, repair and financing) that contribute to the formation and transfer of products to the final stage (M. Ancuţa et al. p.20).

Regarding the agri-food sectors, the inter-professional organizations for food products (OIPA) are defined in the Romanian project on the Strategy for the development of the agri-food sector in the medium and long term 2020-2030 as "a significant part of the production-processing-marketing of products agri-food and have a role in achieving a better capitalization of products".

Partnership approaches for strengthening regional and local markets are also highlighted by the Implementation of the Leader approach for rural development. This implementation is based on the bottom-up approach and not the traditional topdown approach. Leader projects provide useful examples for different types of rural business, namely the involvement of LAGs (Local Action Group) in new ways of cooperation, for stronger gains in rural areas.

\section{The concept of "SHORT CHAIN"}

The definition of the concept of "short food chain" (SFSC) - has been and is the subject of several studies undertaken by researchers in the European Union. In a report (M. Kneafsey et al., 2013 [3]) published by the Joint Research Center (JRC), a 2000 definition was taken as a starting point, emphasizing that the specificity of the short supply chain does not come from the number of intermediaries in the distribution of the product or by the distance that the good travels, although this is essential, but refers to the fact that the product reaches the consumer loaded with information about its production (Marsden et al. 2000).

According to the JRC report, on the basis of some researches carried out in the 2000s, the definition proposed by the French authorities and the European Commission for the short supply chain was defined as follows: "A foodstuff which is presented by the producer or has a traceability to it and which has a minimum or, ideally, zero number of intermediaries between the producer and the consumer."

The 2013 JCR study identified three types of short chains - "face-to-face", "spatial proximity" and "spatial extended". The first category is equivalent to direct sales, the product being purchased by the buyer directly from the manufacturer or processor. This first model ensures the authenticity of the product by the fact that the sale is a personal one. Examples of "face to face sale" are: on-farm sales or other outlets of the manufacturer, markets and roadside sales. This category broadly

Review of International Comparative Management

Volume 22, Issue 1, March 2021 
coincides with the definition of direct selling (Holloway and Kneafsey 2000; Knickel and Hof 2002; Pretty 1998).

In terms of 'spatial proximity', the products are obtained and sold in the region where they were produced, and consumers are provided with information about the quality of the local product at the point of sale. This category includes, in addition to the sales outlets mentioned in the face-to-face case, the specialty stores (delicacies, bakeries, butchers or grocery stores) that sell local products. Also, local restaurants, local hotels and guesthouses could be distributors of these types of products. Also included in this category could be public entities, such as hospitals, schools, universities, prisons, care centers, orphanages and the like, which sell or provide food locally to certain categories of people. At the time of the study, it was pointed out that in some countries there is a tradition of the regional / local supermarket that supplies itself from local sources.

"Spatially extended" is the latest type of SFSC, which has particularities regarding the relationship between product and manufacturer. Although the sale is made outside the region of production, information about the place of processing and production reaches the consumer through labeling, marketing, branding or the use of European certifications. Such products can be sold in any space. The main examples of products that are suitable for marketing in the SFSC in a large space are Protected Designation of Origin (PDO) and Protected Geographical Indication (PGI) (see Barham 2003). These quality systems, as defined by Regulation 1151/2012, transfer the issue of defining the term 'local' from the production area, in terms of geographical location, to the specific characteristics of the product due to the specific characteristics of the raw material (soil, climate, other environmental characteristics) and know-how. However, such SFSCs address more developed businesses, given the certification, verification and labeling costs that such products impose.

Other definitions argue that the number of intermediaries in a short supply chain needs to be as small as possible (eg Ilbery \& Maye 2006) or even zero (Progress Consulting Srl 2010) In the particular case of France there is a consensus that the SFSC should contain maximum one intermediary between producer and consumer (Maréchal 2008; Aubry \& Chiffoleau 2009).

In conclusion, the first two categories of SFSC are closer to the French idea of short chain. Given that both "face to face" and "spatial proximity" are specific to a trade close to the place of production, a new concept has emerged, which encompasses these two types of SFSC and is known as the "local food system" (LFS).

Also, in 2013, the first official definition of the short supply chain appeared in the Regulation 1305/2013 and was similar to the one presented in the JRC report. Thus, " <<short supply chain>> means a supply chain involving a limited number of economic operators engaged in local economic cooperation and development activities, as well as close geographical and social relationships between producers, processors and consumers".

112 Review of International Comparative Management Volume 22, Issue 1, March 2021 


\section{The concept of "LOCAL FOOD SYSTEM"}

EUROPA 2020 Strategy - A European Strategy for Smart, Sustainable and Inclusive Growth" [13] ("Europe 2020 Strategy") introduced for the first time the notion of short chain in close connection with another concept, namely the "local food system" (LFS). The signatory Member States proposed in 2010 a new perspective on the CAP reform, following the economic and financial crisis of 2008. One of the stated objectives was to achieve sustainable growth: promoting a competitive and efficient economy in terms of the use of local resources.

In 2011, proposals were submitted to update the rural development policy, by including policies to promote local products. According to the 2011 Committee of the Regions' forward-looking opinion on local food systems, it was proposed to provide financial incentives to harness local potential to improve the image of lesserknown or often neglected regions.

On 27 January 2011, through the Approval of the Committee of the Regions given upon the theme: "For an ambitious European policy towards agricultural product quality systems" A new approach to local food systems was published in OJ 2011 / C 192/06, with the scope to develop European agriculture by creating added value in rural areas. [14]

The "local food system" is a concept based on the first two categories of short chains (SFSC) which guarantee a higher quality of agri-food products for consumers and a better price for farmers.

The Committee determined that the following components are part of the "local food system (LFS)":

"-A short chain $-<<$ face to face $>>$ or $<<$ spatial proximity $>>$; consumption;

-a small physical distance between the place of production and the place of

-a process, which includes aspects such as transport, distribution, treatment of waste products, renewable energy, marketing, promotion and quality management;

- a local and regional capitalization process.

The opinion of the Committee of the Regions also emphasized that short circuits make it possible to distribute the production of various agricultural products throughout Europe and facilitate the consumption of certain products directly from local markets. Short circuits contribute to a better distribution of agricultural activities throughout Europe and have a positive effect on the environment.

Following the opinion of the Committee of the Regions, which defined the local food system, the European Network for Rural Development (ENRD) decided in the framework of the Working Group on Short Supply Chains (SSC) to launch a publication on "local food systems and food chains". short supply lines, intended to form a focal point for cooperation and exchange of experience within Member States. This publication aimed to disseminate the knowledge gained in short supply chains to a wide audience. At the same time, in order to develop local food systems, the European Agricultural Fund for Rural Development (EAFRD) contributed to 
European rural development policy and presented in the brochure "Examples of EAFRD food projects" the benefits of using European funds.

\section{Benefits of developing local agricultural systems}

According to the U.E. Eurobarometer, 9 out of 10 respondents agreeded that the purchase of local products is beneficial and that the EU must contribute to the development of the rural environment.

The use of such a system brings economic, environmental and social benefits. Streamlining processes by creating a local food system brings financial benefits to farmers, as they will be able to negotiate better selling prices for the goods produced than if they had made a sale through intermediaries or supermarkets where they would have been also required to pay shop fees, shelf fees etc. The creation of a local system would also benefit consumers economically, as they could buy the products at a producer price, without the specific additions of long-distance supply chains. Equally, streamlining production would also benefit the environment by reducing gas emissions and reducing the number of packaging waste resulting from marketing. The social impact would be, notably, through a lower demand for rural roads, reducing traffic congestion and increasing road safety.

In 2010, the Facilitating Alternative Agro Food (FAAN) Project "Local food systems in Europe - Case studies from five countries and what it means for policy and practice" carried out case studies covering different areas of activity and coming from Member States who joined the EU at different times: Austria, England, France, Hungary and Poland. The scientific study was conducted by a team consisting of an academic research institution and a non-governmental body in the field. The conclusions of this study showed the provision of funding facilities in national rural development policies for Local Food Systems (LFS) that will influence local development policies.

\section{The situation of short chains in Romania}

Romania has adapted to the new concept proposed by the short chain. The research of the Romanian entrepreneurial environment and especially the measures that were developed in PNDR 2014-2020 responded to the needs of the development of the sales market on the vegetable-fruit chain. Thus, the project carried out by ICEADR-coordinator, ASE and USAMV was addressed equally to farmers, associations, cooperatives, universities and MADR. The objectives of the project were to streamline market structures and create short chain models to capitalize on fruit and vegetable production.

The novelty of the project consisted in an assessment of the existing situation in Romania regarding the sale of vegetables and fruits by small and medium producers, as well as an analysis on ways to improve their performance on capitalizing on production, by creating and developing short chains. Sources of financing play a very important role in supporting the development of the vegetable

$114 \quad$ Review of International Comparative Management

Volume 22, Issue 1, March 2021 
/ fruit sector consisting of both direct payment schemes (single area payment scheme, redistributive payment, payment for agricultural practices beneficial for climate and environment, payment for young farmers, coupled support, simplified scheme for small farmers), as well as from non-reimbursable funds, meant to contribute to the development or establishment of such businesses in the vegetable sector. The sources of financing come both from the budget of the European Union and from the Government of Romania, in different proportions, the contribution of the European Union being a clearly superior one.

In PNDR 2014-2020, the financing of the vegetable sector benefited from the funds available through:

Sub - measure 4.1 - Investments in agricultural holdings. Public allocation amounting to 877.7 million Euros. Degree of contracting: $100.0 \%$

Sub-measure 4.2 - Support for investments in the processing / marketing and / or development of agricultural products Public allocation amounting to 370.5 million Euros. Degree of contracting: $84.7 \%$

Sub-measure 6.1 - Support for the installation of young farmers public allocation amounting to 436.7 million euros Contracting degree: $99.4 \%$

Strictly regarding the short chain, according to Regulation no. 1305/2013, significant investments were made through PNDR. According to a SWOT analysis carried out by PNDR in the preparation of the new post-2020 National Strategic Plan, through sub-measures 16.4 -Support for horizontal and vertical cooperation between supply chain actors and 16.4a - Support for horizontal and vertical cooperation between supply chain actors, 71 projects worth 6.83 million euros were financed. The supported partnerships involved 186 farmers, 69 schools, health, leisure and public catering, 48 NGOs and 16 local councils.

Table: Situation of funding through PNDR 2014-2020 for measures 16.4 and 16.4a

\begin{tabular}{|l|l|l|l|l|l|l|}
\hline \multicolumn{1}{|c|}{$\begin{array}{c}\text { Sub- } \\
\text { measure }\end{array}$} & $\begin{array}{c}\text { Public } \\
\text { allocation } \\
\text { million } \\
\text { euro }\end{array}$ & $\begin{array}{l}\text { Number of } \\
\text { submission } \\
\text { sessions }\end{array}$ & $\begin{array}{c}\text { Allocation } \\
\text { million euro }\end{array}$ & $\begin{array}{c}\text { Submitted } \\
\text { projects }\end{array}$ & $\begin{array}{l}\text { Selected } \\
\text { projects } / \\
\text { value }\end{array}$ & $\begin{array}{l}\text { Contracts } \\
\text { projects / } \\
\text { value / } \\
\text { payments }\end{array}$ \\
\hline $\begin{array}{l}\text { Sub-measure } \\
16.4 \\
\text { "Support for } \\
\text { horizontal } \\
\text { and vertical } \\
\text { cooperation } \\
\text { between } \\
\text { actors in the } \\
\text { supply chain" }\end{array}$ & 10,1 & $\begin{array}{l}4(2 \text { in } 2016, \\
1 \text { in } 2017 \\
\text { and } \\
1 \text { in } 2019)\end{array}$ & 15,6 & 266 & $\begin{array}{l}\text { selected: } \\
60 \\
\text { projects }\end{array}$ & $\begin{array}{l}\text { Contract: } \\
21 \text { projects } \\
\text { total value } \\
4,6 \text { mil. } \\
\text { Euro }\end{array}$ \\
\hline $\begin{array}{l}\text { Sub-measure } \\
16.4 a\end{array}$ & 8,7 & 4 & 14,2 & 79 & $\begin{array}{l}\text { total valuelected: } \\
5,7 \text { mil. } \\
\text { euro }\end{array}$ & $\begin{array}{l}\text { Contracts: } \\
\text { "Support for } \\
\text { horizontal } \\
\text { and vertical }\end{array}$
\end{tabular}

Review of International Comparative Management

Volume 22, Issue 1, March 2021 


\begin{tabular}{|c|c|c|c|c|c|c|}
\hline $\begin{array}{c}\text { Sub- } \\
\text { measure }\end{array}$ & $\begin{array}{c}\text { Public } \\
\text { allocation } \\
\text { million } \\
\text { euro } \\
\end{array}$ & $\begin{array}{c}\text { Number of } \\
\text { submission } \\
\text { sessions }\end{array}$ & $\begin{array}{l}\text { Allocation } \\
\text { million euro }\end{array}$ & $\begin{array}{c}\text { Submitted } \\
\text { projects }\end{array}$ & $\begin{array}{c}\text { Selected } \\
\text { projects / } \\
\text { value }\end{array}$ & $\begin{array}{c}\text { Contracts } \\
\text { projects / } \\
\text { value / } \\
\text { payments }\end{array}$ \\
\hline $\begin{array}{l}\text { cooperation } \\
\text { between } \\
\text { actors in the } \\
\text { supply chain" }\end{array}$ & & 1 in 2019) & & & $\begin{array}{l}\text { total value } \\
4,0 \text { mil. } \\
\text { euro }\end{array}$ & $\begin{array}{l}\text { total value } \\
4,6 \text { mil. } \\
\text { Euro } \\
\text { payments } \\
\text { made: } 1,9 \\
\text { mil. euro }\end{array}$ \\
\hline
\end{tabular}

A support model for facilitating short chains for local products in the Transylvania area, especially in Cluj County, is the "Product of Cluj" Association. The organization provides support through a direct relationship between the producer and consumers by organizing trade fairs at regional level. The association turns 10 this year, and among the founding members are the Cluj County Council, the Cluj County Center for the Preservation and Promotion of Traditional Culture (CJCPCTC) and Agro Transilvania. This association brings together, throughout the producers who exhibit the products at the thematic fairs, the components of a local food system:

1. a short chain - because at these events are directly present the producers who carry out an economic activity in Cluj County on different categories of products: milk, fruits and vegetables, cold pressed oils, beekeepers, but also small farmers who sell cheese, products pork, jams, gingerbread, all prepared according to recipes passed down from generation to generation;

2. a small physical distance between the place of production and the place of consumption - because everything is done in the area of the Transylvania region maximum $100 \mathrm{~km}$;

3. a process, which includes aspects such as transport, distribution, treatment of waste products, renewable energy, marketing, promotion and quality management - because all processes are carried out by the manufacturer, with its own raw material, and the promotion is done by the association;

4. a process of capitalization directed at local and regional level - the manifestations have a constant in space and time, being known in the region.

Regarding the term food chain, the National Interprofessional Organization Prodcom Vegetables-Fruits (OIPA) carries out an activity recognized by MADR, which involves providing coupled support for vegetables in greenhouses and solariums (tomato program) or promoting Romanian products on foreign markets, with major benefits for the development of members of the fruit and vegetable sector. 


\section{Conclusions}

The short supply chain, especially with seasonal products, is a beneficial alternative for farmers and consumers. European Community countries have experienced various variants of a direct producer-consumer link. Community legislation has created the general framework and encourages local initiatives for direct selling.

LAGs have been set up in Romania, which organize the activities of small and medium-sized enterprises. Priority projects of LAGs are related to the short supply chain with seasonal products. The Government of Romania supports with priority the development of small and medium farms through the help offered in accessing European funds.

The design of a high-performance agri-food chain cannot be achieved without the cooperation of agricultural producers in order to obtain better conditions for capitalizing on products and counterbalancing power along the food chain. In the countries of the European Union and the United States, cooperation is a widespread form of organization and the main difference between an agri-food chain and a local agri-food system is given by the distance that the product travels from the raw material to the buyer.

An example of good practices in Romania, in terms of the agri-food sector, is presented by OIPA Fruit and Vegetables, which carries out capitalization and promotion actions for fresh fruits and vegetables in partnership with a consortium from Greece. The products inside the program consist of fresh fruits (kiwi from Greece) and fresh European vegetables (tomatoes and cucumbers from Romania) distributed on the markets of the Czech Republic, Slovakia, Germany and Poland.

The model of agro-industrial integration in developed countries is characterized by the increasing impact of industrialization on agri-food chains, the development of secondary and tertiary activities, the generalization of modern production methods, mass production and distribution, increasing energy consumption, intermediate and capital consumption per unit of work, and on this basis, achieving high labor productivity and reducing the number of farmers.

For Romania, the models that have developed as examples of good practice are direct sales. The consumer buys local, organic, fresh, traditional products directly from the manufacturer through local fairs organized on the weekends. At the same time, by promoting local farmers, processors by strengthening marketing policies, the volume of sales in convenience stores has increased. The models that use a distribution chain aim at optimizing the stocks, ensuring the rhythmicity of the supply, reducing the costs within the short supply chain. Furthermore, this aspect requires a detailed study to identify an optimal sustainable solution for the business environment in various sectors of the agri-food sector and for the Romanian society. The options of the association either in a group of producers / agricultural cooperative or another organizational form within sectoral and regional programs that will have to take into account the authentic value of the natural, material, social and human heritage specific to Romania in compliance with EU legislation. 


\section{References}

1. Aubry C. and Chiffoleau Y., 2009. Le développement des circuits courts et l'agriculture périurbaine: histoire, évolution en cours et questions actuelles. Innovations Agronomiques (2009) 5, pp. 53-67.

2. Barham E., 2003. Translating Terroir: The Global Challenge of French AOC Labeling. Journal of Rural Studies 19, pp. 127-38.

3. Henk R., 2003. Understanding Alternative Food Networks: Exploring the Role of Short Food Supply Chains in Rural Development. Environment and Planning A 20 03, volume 35 , pp. $393-411$.

4. Holloway L. and Kneafsey, 2000, Reading the space of the farmers' market: a case study from the United Kingdom. Sociologia Ruralis 40, pp. 285-299.

5. Ilbery B. and Maye D., 2006. Retailing local food in the Scottish-English borders: a supply chain perspective. Geoforum 37 (3), pp. 352-367.

6. Knickel K., Hof S, 2002. "Direct retailing in Germany: farmer markets in Frankfurt", in Living Countrysides. Rural Development Processes in Europe: The State of the Art Eds D van der Ploeg, J Banks, A Long (Elseviers, Doetinchem), pp. 104-112.

7. Maréchal G., 2008. Les circuits courts alimentaires: bien manger dans les territories. Editions Educagri.

8. Marin A., Ion R., Chetroiu R., Iurchevici L., 2018. Ghid practic pentru infiintarea unui lant scurt de valorificare a productiei de legume si fructe. Editura ASE, Bucuresti.

9. Moya K. et al., 2013. Short Food Supply Chains and Local Food Systems in the EU. A State of Play of their Socio-Economic Characteristics. European Commission Joint Research Centre Institute for Prospective Technological Studies.

10. Petersen B., Nussel M. and Hamer M. (eds.), 2014. Quality and Risk Management in Agri-Food Chains. The Netherlands: Wageningen Academic Publishers.

11. Pretty J., 1998. The Living Land: Agriculture, Food and Community Regeneration in Rural Europe. Earthscan, London.

12. Progress Consulting Srl (2010) "Marketing on local markets”. Brussels: European Union.

13. Zecca F., Rastorgueva, N., 2014. Supply Chain Management and Sustainability in AgriFood System: Italian Evidence. Journal of Nutritional Ecology and Food Research Vol. 2, pp. 20-28.

14. European Commission, 2011. The Common Agricultural Policy. Special Eurobarometer Report 368 (September 2011), survey co-ordinated by DG COMM, Brussels - available at: http://ec.europa.eu/public_opinion/archives/ebs/ebs_ 368_en.pdf [Accessed December 2020]

15. European Commission, 2011. Opinion of the Committee of the Regions on 'The CAP towards 2020: Meeting the food, natural resources and territorial challenges of the future' (2011/C 192/05). Official Journal of the European Union. Brussels - available at: https://eur-lex.europa.eu/legal-content/EN/TXT/HTML/?uri=CELEX:52011AR 0016\&from=RO. [Accessed December 2020]

16. European Commission, 2011. Opinion of the Committee of the Regions on 'Towards an ambitious European policy for agricultural quality schemes' (2011/C 192/06). Official Journal of the European Union. Brussels - available at: https://eur-lex.europa.eu/legalcontent/EN/TXT/HTML/?uri=CELEX:52011AR0014\&from=RO. December 2020] 
17. European Commission, 2012. EU Rural Review. A publication from the European Network forRural Development. Printed in Belgium, available at: https://enrd.ec.europa.eu/sites/enrd/files/E8F24E08-0A45-F272-33FB-

A6309E3AD601.pdf [Accessed December 2020]

18. European Commission, 2020. COM(2010) 2020 final, Europe 2020: A strategy for smart, sustainable and inclusive growth. Available at: https://eurlex.europa.eu/lexuriserv/lexuriserv.do?uri=com:2010:2020:fin:en:pdf [Accessed December 2020].

19. European Commission, 2010. Local Food Systems in Europe Case studies from five countries and what they imply for policy and practice. FAAN - Facilitating Alternative Agro-Food Networks (AAFNs): Stakeholder Perspectives on Research Needs (217820). Available at: https://zenodo.org/record/1184115\#.YA9O7OgzaUk [Accessed December 2020].

20. European court of auditors, 2010. Implementation of the leader approach for rural development. Available at: https://www.eca.europa.eu/Lists/ECADocuments/ SR10_05/SR10_05_EN.PDF [Accessed December 2020].

21. Romania Ministry of Agriculture. Swot Analysis regarding National Statistical Plan 2021-2027, Available at: https://www.madr.ro/docs/dezvoltare-rurala/PAC_dupa_ 2020/2020/DRAFT-Analiza-SWOT-Plan-National-Strategic-2021-2027.pdf,

[Accessed March 2020].

22. https://sites.google.com/a/iceadr.ro/institut/proiecte1

23. Romania Government Emergency Ordinance no103/2008 regarding the creation and functioning of inter-professional organisations fora product or group of agri-food products Available at: http://legislatie.just.ro/Public/DetaliiDocument/97170, [Accessed March 2020]. 